\title{
ВЕРБАЛІЗАЦІЯ ТАБУ, ПОВ'ЯЗАНИХ ІЗ ХВОРОБАМИ ЛЮДИНИ
}

Єловська Ю. В. Вербалізація табу, пов'язаних із хворобами людини.

У статті проаналізовано словесні та комунікативні табу, пов'язані з хворобами людини. Виявлено чинники, що сприяють виникненню таких заборон, та визначено способи заміщення табуйованих одиниць, якими послуговуються мовці. 3'ясовано особливості функціонування таких табу на сучасному етапі, зокрема в міжосособистісному спілкуванні. Акцентовано на тому, що табуїзації підлягають як окремі номінації, так і обговорення хворобливого стану людини або їі здоров’я загалом, частково забороненим стає спілкування на тему хвороб у певному колі осіб, однак сучасні тенденції в мовленнєвій практиці українців характеризуються процесами детабуїзації цих пересторог.

Ключові слова: табу, заборона, мовець, комунікативна ситуація, евфемізм.

Еловская Ю. В. Вербализация табу, связанных с болезнями человека.

В статье анализируются словесные и коммуникативные табу, связанные с болезнями человека. Выявляются факторы, которые способствуют возникновению таких запретов, и определены способы замещения табуированных единиц, которые использует говорящий. Раскрываются особенности функционирования таких табу на современном этапе. Акцентируется внимание на том, что табуизации поддаются как отдельные номинации, так и обсуждение болезненного состояния человека или его здоровья вообще, частично запрещенным становится общение на тему болезней в определенном кругу лиц, однако современные тенденции в речевой практике украинцев характеризуются процессами детабуизации этих предостережений.

Ключевые слова: табу, запрет, говорящий, коммуникативная ситуация, эвфемизм.

Yelovska Yu. V. The verbalization of taboos associated with human illnesses.

The general tendency of modern linguistics is oriented towards the comprehensive analysis of language phenomena through the prism of a functional and pragmatic approach. It studies the functions of language units in their interaction with the conditions and tasks of communication. Scientific researches of recent decades are devoted to systematizing general theory principles of communication, the development of the term and methodology definitions, descriptive structures of the communicative act, etc. The main attention of receint researching is focused on describing the strategies and tactics of successful interpersonal and intercultural communication. It is important to investigate factors influencing a communicative act, in 
particular studying rules, norms and taboos, created to provide successful speaking. Taboo in communication is a kind of protective barrier that prevents moral harm to an interlocutor, and regulates communication behavior. Following prohibitions, along with the principles of courtesy and cooperation, contributes to the successful communication.

Analysis of Ukrainian speech practice and fragments of folklore and texts of Ukrainian literature in the end of the XIX - early XXI centuries represents partial verbal and thematic taboos associated with diseases. These partial bans are put on certain categories, as well as discussing the weak condition of a person or his or her health in general. Any disease is concidered to be a living being coming from the other world due to pronuncing by the speaker its name. Such sort of superstition causes the conscious avoidance of these language units in speech. As a result, the words defying human diseases in the speech of Ukrainians become undesirable, and therefore, partially prohibited. This conscious avoidance is connected with the unconventional understanding of a verbal sign and the referential peculiarities of object or reality phenomenon names. It logically brings the formation of numerous word substitutes for the most terrible diseases. Correct decoding of such information messages requires the knowledge of folklore and the symptoms of corresponding illnesses. Also it requires taking into account the context in order to understand the addressee's thought accurately. In addition communication on the topic of illness is partially forbidden in a certain group of people. However, the current trends in the speech practice of Ukrainians are characterized by the processes of lifting these bans.

Key words: taboo, prohibition, speaker, communicative situation, euphemism.

Загальні тенденції сучасного мовознавства орієнтують науковців на комплексний аналіз мовних явищ крізь призму функційно-прагматичного підходу, який передбачає студіювання функцій мовних елементів у їхній взаємодії з умовами й завданнями спілкування. Наукові розвідки останніх десятиліть присвячені систематизації загальних теоретичних засад спілкування, розробленню термінологічного й методологічного апарату, описові структури комунікативного акту тощо. Значне місце в дослідженнях належить характеристиці стратегій i тактик успішного міжособистісного й міжкультурного спілкування. Значущим $\epsilon$ виявлення чинників, що впливають на перебіг комунікативного акту, зокрема правил, норм і табу, покликаних сприяти його успішності. Вивченню феномена «табу» присвячені численні розвідки українських і зарубіжних фахівців (К. Аллан, О. Бабаєва, Ф. Бацевич, Кр. Бейлі, К. Берідж, Х. Вебстер, Р. Газізов, Дж. Глісон, Т. Джей , Д. Зеленін, Н. Мечковська, В. Півнюк, Я. Попова, А. Редкліфф-Браун, О. Рутер, Л. Фроляк, К. Харріс, Г. Шредер та ін.). Однак перспективною $є$ потреба грунтовної деталізації, систематизації й аналізу табу крізь призму українського мовленнєвого простору, та виявлення 
національно-специфічних особливостей цього феномена, притаманних мовленню українців.

Табу являє собою заборону, накладену на об'єкти дійсності (предмети побуту, їж, місця перебування) і певні види діяльності. У мовознавчому аспекті табу - це будь-яке ситуативне обмеження або застереження щодо вживання в мовленні певних мовних одиниць (слів, словосполучень тощо), тактик, а також уникання спілкування 3 окремими особами або ведення комунікації як такої за певних часово-просторових умов, що детерміноване різними причинами, зокрема релігійними, магічними, суспільно-політичними, культурними, морально-етичними тощо.

Табу у спілкуванні стає своєрідним захисним бар'єром, який перешкоджає нанесенню моральної шкоди співрозмовникові, і покликаний регулювати мовленнєву поведінку комуніканта. Дотримання заборон поряд із принципами ввічливості й кооперації сприяє успішному протіканню комунікації.

Аналіз мовленнєвої практики українців свідчить про наявність повної або часткової табуїзації мовних одиниць на позначення біологічної природи та суспільної поведінки людини. Метою цієї розвідки $є$ вивчення вербальної актуалізації табуйованих смислів, пов'язаних iз біологічною природою людини, зокрема тих, що репрезентують порушення фізіологічних i психічних функцій організму вказує на його нездоровий стан. Інтегральною семою зазначених заборон $є$ визначення хвороби - «порушення нормальної життєдіяльності організму під впливом несприятливих чинників внутрішнього й зовнішнього середовища» [11, с. 47]. Нагадаємо, що табуюванню підлягають не самі явища, а лише їхні номінації.

Спостереження за мовленнєвою практикою українців та аналіз фрагментів фольклору й текстів української літератури кінця XIX початку XXI ст. дають змогу твердити про наявність часткових словесних i тематичних табу, пов'язаних із хворобами. Частковій табуїзації підлягають як окремі номінації, так i обговорення хворобливого стану людини або іï здоров'я загалом.

Хворобу в уявленнях українців ще з часів язичництва пов'язували 3 дією зловісної магічної сили (уроки) або духів, поширених у брудних і небезпечних місцинах $[2$, с. 211-216]. Закономірним $\epsilon$ те, що у свідомості українців хвороба постає персоніфікованою сутністю. О. Хомік справедливо зазначає: «захворювання частіше репрезентоване с Ю. В. Єловська, 2017. 
мовними одиницями на позначення дівчини, жінки, старої та розкривають симптоми захворювання: гнетуха, задуха, падалка, холодуха, студентка, чихавка» [18, с. 13].

Усвідомлення хвороб як живих істот, що приходять із потойбічного світу завдяки промовлянню мовцем їхніх імен, спонукає до свідомого уникання в мовленні їхніх лінгвальних репрезентантів. У результаті слова на позначення хвороб людини в мовленні українців стають небажаними, а отже, частково табуйованими. В основі свідомого уникання назв хвороб лежить неконвенційне розуміння мовного знака, фетишизація імені, апеляція до референційних особливостей номінацій об’єктів та явищ дійсності. Логічною є поява численних слів-замінників найстрашніших захворювань. В українській мові збереглися позначення деяких хвороб не тільки в їхніх прямих назвах, наприклад, лихоманка, вісnа, холера, а й у ряді евфемізмів, які, за народним повір'ям, при вживанні були своєрідними мовленнєвими оберегами. Д. Зеленін групує ці назви за такими категоріями: ласкаві іменникові звертання й назви, що виражають повагу (кума, тітка, панна); назви-натяки, частіше виражені вказівними та особовими займенниками (ma, кого не називають; вона); назви образливого характеру, здебільшого представлені субстантивованими прикметниками (поганка, лиха, худа). Зазначені слова-замінники говорять про бажання комунікантів утриматися від прямого називання хвороб, а виникнення цих евфемізмів зумовлене побоюваннями накликати хворобу на себе, промовляючи іiі імення $[11$, c. $64-65,77,152-155]$.

Чимало перифраз страшних хвороб фіксуємо у творах української літератури. Наприклад, лихоманка в народній уяві являє собою Іродову доньку Трясавицю. Примітним є те, що найбільш уживані слова на позначення цього захворювання маніфестують суто іменники жіночого роду, як-от: пропасниця й трясовиця та їхні лексико-семантичні варіанти трясия, трясовицяя: I трясця без причини не бере (16, с. 326); $<\ldots>$ Шіпле-дівице, Пропаснице-трясовице! Іди собі на купя, на болота <...> не тут тобі ходити, білого тіла не вялити, жсвтої кості не млоїти, чорної крові не спивати, віку не вкорочати (15, с. 390-391); $<\ldots>$ Ану, давай розтирати разом, щзоб $і$ мороз, $і$ трясця, $i$ застуда заразом утікали з ніс (12, с. 144). Аналогічну тенденцію в українському комунікативному просторі спостерігаємо й зі словом чума. Ця хвороба 
так само персоніфікується у свідомості українців й уособлює багату панянку, що їздить в екіпажі з шістьма кіньми [2, с. 217]. Експліцитна мовна одиниця отримує евфемістичне заміщення через іменник пані: $<\ldots>$ Мамо, спиталася Ганнуся хрипким голосом, пощу там та пані сидить на тому возі? - Яка пані, де? - а он-о, чи ж не бачите <..> Марія ходила <..> вже не сумніваючись, щзо тоді на ярмарку Ганнуся справді бачила <..> саму чуму, яку ще тоді, можна було відвернути $<\ldots>(13$, c. 313$)$. Прямих номінацій апоплексичного удару чи паралічу також уникають, заміщуючи їх словом грещ̧ь або описовими конструкціями, які в своєму значенні містять симптоми недуги: Лежить без язика. За лікарем кинулися посилати $<\ldots>$ Як колода лежить і не ворухнеться < .. > Пана грець ударив (8, с. 143).

Саме слово хвороба та його лексико-семантичні варіанти (хворий, хвора, хворобливий) подекуди підлягають заміщенню, що спонукає долучити їх до корпусу частково табуйованої лексики. Найбільш частотною $є$ заміна цих мовних одиниць у значенні «Тяжкохворий». У паремійному корпусі фіксуємо чимало зразків: Змарнів як полова (16, с. 368); Упав з лиця (16, с. 368); Од вітру валиться (16, с. 368). Наведені ілюстрації семантично репрезентують нездоровий стан людини, зокрема різку втрату ваги, що є характерним симптомом певних захворювань. Два наступні приклади $\boldsymbol{H i}$ ж⿻е, ні гниє (16, с. 368); Тільки жсивий та теплий (10, с. 24) демонструють наявність у людини лише первинних життєвих показників, що надає адресатові згорнуту інформацію про вкрай тяжкий стан хворого.

Нерідко, аби уникнути використання в мовленні експліцитних репрезентантів різноманітних хвороб, комуніканти послуговуються складними описовими конструкціями. Прикметним $\epsilon$ те, що ці структури описують здебільшого симптоми недуги, починаючи від загальновідомих ознак (почуття слабкості), до конкретизації місця ураження захворювання (горло, груди, шлунок) або певних фізіологічних реакцій організму, що перебуває в хворобливому стані (кашель, судоми, тиск): Як рипить у грудях, не будь на людях (16, с. 605); Він лежсав на тапчані, жсовтий, худий на лиці, від голови ажс палахтіла гарячка <..> в горлі почало хрипіти, а, крім глибокого, роздираючого стогнання, ніякий голос не добувся з його уст <..> дихавиця дуиила його щораз, то страшніше (17, с. 362); Охолонув лобик. А то ж хорів, як жсарина <...> Не спав, в гарячџі був. Без пам'яті був трохи не три дні. Так тебе тіпало, бідолагу, щэо аж ๑ Ю. В. Єловська, 2017. 
підкидало на ліжку (14, с. 113); Прокинувся він на світанку з хворобою в грудях, ії вже не змогли вигнати ні піч, ні парене зерно, ні добра чарка. Через три дні спочивав у домовині (12, с. 158); До слова, пані Слава також запрошувала на чай з печивом (не кава - у неї тиски) (4, с. 82).

Стан здоров'я людини, зокрема хворобливий, стає предметом обговорення лише з певним колом осіб (наприклад, родичі та близькі, лікар), з рештою співрозмовників спілкування на цю тему є частково обмеженим. Необхідність дотримання цього табу набуває особливої значущості в разі згадування невиліковних захворювань: «Валю, повір мені, твою хворобу можна вилікувати <... «Давай про ие більше ніколи не говорити <..> $>$ - реаліст $i$ знаю чим воно все закінчиться» (7, с. 92). Подвійне заперечення, виражене в репліці адресата заперечним прислівником ніколи й заперечною часткою не у препозиції до інфінітивної форми дієслова (не говорити), підкреслює неприйнятність цієї розмови та надає відповіді адресата відтінку роздратованості зайвою зацікавленістю адресанта цією проблемою.

В українському паремійному корпусі так само фіксуємо зразки імпліцитних порад, які вказують на зайвість запитань про здоров'я мовця, особливо якщо він перебуває у хворобливому стані: Не питай «Як ся маєш?»- подивись, то пізнаєш (16, с. 28); Хіба треба й недужого питати, чи бажає він здоров'я мати (9, с. 604). У перших прикладах зовнішні ознаки, які може спостерігати адресат через власні зорові аналізатори, надають йому достатню інформацію про фізіологічний стан адресанта, тому додаткові запитання є недоречними. Послуговуючись дієслівними формами наказового способу із заперечною часткою не у препозиції до присудка, мовець застерігає адресата від надмірної цікавості (не питай). Контекстуальне роз'яснення сигналізує, що достатньо зорового контакту, аби отримати бажану інформацію. Риторична форма третьої ілюстрації також натякає на нечемність подібних запитань.

На нашу думку, такі заборони варто вважати ситуативно зумовленими, оскільки вони характерні лише для тих комунікативних ситуацій, де співрозмовники не мають достатнього рівня довіри й відкритості спілкування. До того ж аналіз сучасного комунікативного простору i творів українських класиків другої половини ХХ ст. початку XXI ст. дає підстави твердити про вільне вживання мовних одиниць на позначення різних хвороб без будь-яких обмежень, що 
демонструє детабуїзацію цієї заборони. На підтвердження висловлених міркувань наводимо зразки текстових уривків, які репрезентують експліцитні назви різних захворювань: <..> директор радгоспу Пахом Хрисантович, сухарюватий, хворий на виразку шлунка чоловічок < .. > Привезли його вчора сюди, лікарка оглянула: підозра на стовбняк <..> (3, с. 45); < ..> як не допустив би чуми, сифілісу, ядерної бомби, - погоджувався сизоносий випивоха, який виринув на хвильку біля нашого столика (1, с. 63).

Результати спостереження за мовленнєвою практикою Криворізького регіону дає підстави твердити про вільне називання хвороб. Хоч зауважимо, що більшість опитаних чітко окреслює коло осіб, з якими вони готові обговорювати розлади у психосоматиці тіла, зокрема з близькими друзями або родичами. Лише незначна кількість респондентів (приблизно 12\%) уникає розмов на тему хвороб чи хворобливого стану. Серед причин, що зумовлюють обмеження у спілкуванні в цьому аспекті, наявні як забобони («говорю, але дуже поверхнево, на собі не показую, бо вважаю, щзо ия хвороба може перейти на мене»; «не кажу, бо ие може статися зі мною»), так і бажання адресанта дотримуватися максими тактовності («про чужі хвороби говорити негарно»; «не говорю, бо иее особисте»; «людині ияе може бути неприємно»).

Узагальнюючи сказане, гадаємо, що адресант свідомо уникає експліцитних назв, аби не наврочити собі хворобу. Тому очевидною $\epsilon$ необхідність долучити цю лексику до корпусу частково табуйованої. Правильне декодування таких інформаційних повідомлень вимагає від адресата знання народного фольклору чи симптомів відповідної недуги, а контекстуальний супровід поданих вище уривків сприяє точному розумінню думки адресанта. Частково забороненим стає спілкування на тему хвороб у певному колі осіб. Однак сучасні тенденції в мовленнєвій практиці українців характеризуються процесами детабуїзації цих пересторог.

\section{Література}

1. Андрухович Ю. Московіада : [роман] / Ю. Андрухович. - Івано-Франківськ : Лілея-НВ, 2000. - $152 \mathrm{c.}$

2. Булашев Г. О. Український народ у своїх легендах, релігійних поглядах та віруваннях / Георгій Онисимович Булашев. - К. : Довіра, 1992. - 415 с.

3. Гончар О. Т. Твори : у 7 т. / О. Т. Гончар. - Т. 5. : Тронка : Роман у новелах ; Бригантина : повість. - К. : Дніпро, 1988. - 487 с.

4. Дереш Л. Культ : [роман] / Л. Дереш. - Х. : Фоліо, 2010. - 218 с.

() Ю. В. Єловська, 2017. 
5. Довженко О. П. Вибрані твори / О. П. Довженко. - Одеса : Маяк, 1976. - 147 с.

6. Зеленин Д. К. Табу слов у народов Восточной Европы и Северной Азии/ Д. К. Зеленин // Сб. музея антропологии и этнографии. $-1930 .-$ Т. IX. -164 с.

7. Зборовська Н. Українська реконкіста : [антироман] / Н. Зборовська. - Тернопіль : Джура, 2003. - 304 с.

8. Мирний П. Твори : у 2 т. / Панас Мирний. - Т. 1 : Оповідання. Повісті. Романи. Драматичні твори (1872-1898). - К. : Наук. думка, 1989. - 752 с.

9. Прислів'я та приказки : Взаємини між людьми / [упоряд. М. М. Пазяк]. - К. : Наук. думка, 1991. - 440 с.

10. Северинюк В. М. Тематичний словник популярних українських прислів”їв та приказок / В. М. Северинюк. - Тернопіль : Навч. книга - Богдан. - 2014. - 176 с.

11. Словник української мови : в 11-и т. / гол. ред. І. К. Білодід. - К. : Наук. думка, 1980. - T. XI. -699 c.

12. Стельмах М. П. Вибрані твори : у 2 т. / М. П. Стельмах. - Т. 2 : Гуси-лебеді летять. Щедрий вечір. - К. : Український письменник, 2003 - 266 с.

13. Сучасна українська література кінця XX ст. - початку XXI ст. / упоряд. текстів I. М. Андрусяк. - К. : Школа, 2006. - 464 с.

14. Тютюнник Г. М. Твори. Оповідання / Г. М. Тютюнник. - К. : Молодь, 1984. -328 с.

15. Українка Л. Вибрані твори : поезії ; поеми ; драматичні твори / Леся Українка. - К. : Дніпро, 1974. - 630 с.

16. Українські прислів'я і приказки / уклад. М. Номис. - К. : Либідь, 1993. -768 с.

17. Франко I. Зібрання творів у п’ятдесяти томах / I. Франко. - Т. 14 : Повісті та оповідання (1890-1910). - К. : Наук. думка, 1978. - 485 с.

18. Хомік О. Є. Український вербальний оберег : семантика і структура : автореф. дис. ... канд. філол. наук / О. Є. Хомік. - Х., 2005. - 22 с.

Стаття надійшла до редакиії 06.10.2017 p. 